\title{
Skrivelse til Amtsdommer Schultze, Nørborg.
}

\section{Ved Nis Nissen.}

Som Eksempel paa et godt Forhold mellem den danske Befolkning paa Als og en typisk Embedsmand, der i Aarene op til Verdenskrigen virkede som Amtsdommer $i$ Nørborg, tjener følgende Skrivelse:

Hr. Amtsdommer Schultze,

Nørborg.

Ved Deres Nedlæggelse af Dommerembedet her og Afrejse fra Nørborg føler undertegnede Trang til at udtale for Dem vor Beklagelse af Deres Bortrejse, vor Tillid, Højagtelse og Erkendtlighed for Deres Upartiskhed som Dommer, for Deres vellykkede Stræben efter at forstaa os, vort Lands Kultur og de vanskelige Forhold hvori vi lever som Grænsebefolkning.

Til vor varme Anerkendelse heraf vil vi føje en Tak for den smukke og hensynsfulde Maade, hvorpaa De har stillet Dem til vort danske Folkesprog. Det har været os en Glæde, at De i saa kort Tid har naaet at beherske det, og vi takker Dern for den flittige Brug, De har gjort af det i Retssalen i alle de Tilfælde, hvor det tiltrængtes for den rette Forstaaelse. Af alle disse Grunde havde vi gerne set, at De var forbleven her.

Vore bedste Ønsker for Deres Livsgerning og Fremtidshjem følger Dem paa Vej.

3. Juli 1913.

Nis Nissen, Nørborg, Peter Grau, Pøl, Jørgen Eriksen Petersen, Havnbjerg, Hans Hansen, Stevning. 